\title{
Coffee Anyone? - Part 2: Additional Business Opportunity Statements For Unstructured Capital Budgeting Projects
}

\author{
Katherine J. Silvester, Siena College, USA
}

\begin{abstract}
This paper builds on an earlier paper that presented an unstructured, semester-long team-based capital budgeting project for senior level undergraduate accounting students. Successfully completing this project required accounting students to step outside of their narrow accounting transactions framework and to apply extensive organizational, analytical, information gathering, and critical thinking skills. This extension paper provides two additional Business Opportunity Statements that can be assigned to student groups for semester projects. Utilizing these additional Statements will allow faculty to challenge consecutive semesters of students.
\end{abstract}

Keywords: Capital Budgeting; Market Opportunity; Unstructured Analysis; Critical Thinking; Student Project; Business Plan

\section{INTRODUCTION}

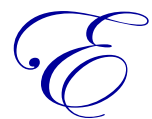

ncouraging, developing, and nurturing critical thinking skills among accounting students is a continuing challenge. Historically, traditional accounting education has been heavily invested in structured, rulesbased approaches to problem solving. These approaches tend to stress memorization of definitions and rules, and the subsequent structured application of the memorized material to constrained problem solving. These activities generally correspond to Bloom's (1956) lower cognitive levels of Knowledge, Comprehension, and Application. In order to develop their critical thinking skills, however, students need to move beyond these lower level skills. Students need to develop the higher level skill sets involved in Analysis, Synthesis, and Evaluation in order to solve the unconstrained and ill-defined problems that they will encounter in the "real world." Guided educational experiences that introduce students to ill-defined problem solving can help students to develop these necessary critical thinking skills.

\section{PROJECT DESCRIPTION}

Silvester (2012) presented an extensive description of a team-based semester-long capital budgeting project for senior level accounting students. The detailed description contained: (1) a team project description, (2) a schedule of project deliverables and their specific content, (3) teaching insights and guide lines, and (4) suggested spreadsheet formats for project cash flow and income analysis. This original project also included a Business Opportunity Statement (entitled "Coffee Anyone?") that described the need for coffee, beverage, and snack services in a college academic building.

In order to prevent students in subsequent semesters from simply copying and/or duplicating solutions to the original "Coffee Anyone?" project, additional Business Opportunity Statements have been developed for use with the original project. These Statements are designed so that the typical senior level accounting student can analyze a market opportunity, without the need for additional technical training or background.

The two scenarios contained in this paper require student teams to create a new business plan in response to different needs that might be encountered in a college campus. Appendix 1 ("Kids Anyone?") describes the child 
care needs of part-time older students pursuing a college education at night. Appendix 2 ("Fun Anyone?") describes the need for regular on-campus weekend entertainment for residential college students. Both appendices describe a market business opportunity and relevant factors for consideration (e.g., cost, security, safety, etc.).

In order to complete these projects, students will need to employ significant critical thinking skills. They will need to analyze the business opportunity, synthesize a business response, and then evaluate the financial viability of their response.

\section{CONCLUSION}

This paper presents two market opportunity scenarios for use by students in a capital budgeting project. Both of these scenarios allow advanced accounting students to go through the entire new business plan and capital budgeting process, without needing extensive additional technical knowledge.

\section{AUTHOR INFORMATION}

Katherine J. Silvester, Ph.D. is an Associate Professor of Accounting in the Department of Accounting and Business Law at Siena College in Loudonville, NY. She earned her Ph.D. in Accounting from the University of Maryland in College Park. Her primary teaching and research interests lie in the areas of managerial/cost accounting and accounting pedagogy. She has previously published in journals such as the Journal of Business Case Studies, the Journal of Accounting Case Research, and the Journal of Accounting and Public Policy. E-mail: ksilvester@siena.edu

\section{REFERENCES}

1. Bloom, B. S., editor. 1956. Taxonomy of Educational Objectives, The Classification of Educational Goals, Handbook I: Cognitive Domain. New York, NY: Longman Inc.

2. Silvester, K. 2012. "Coffee Anyone? An Unstructured Capital Budgeting Project To Encourage Critical Thinking Skills In Accounting Students.” The Journal of Business Case Studies 8 (2), pp. 223-236. 


\section{APPENDIX 1}

\section{Business Opportunity Statement}

Kids Anyone?

Stanton College is a small, Liberal Arts residential college located outside of Boston, Massachusetts. Its 3,000 students are evenly distributed among its three major schools of Liberal Arts, Science, and Business. Historically, Stanton has concentrated on full-time Bachelors and Masters Programs and almost $90 \%$ of its students live on campus. At this point in time, Stanton has reached its absolute limits for full-time day enrollments in terms of both on-campus housing and day-time classroom utilization.

Interestingly, Stanton's classrooms are virtually empty during the evenings and summer periods. As an experiment, Stanton has recently begun offering evening Business classes for part-time students. This has been a huge initial success, and the evening sections are filled to capacity. Given this encouraging start, Stanton intends to extend its evening offerings and to offer a number of part-time classes leading to a Bachelors or Masters in Business. As a side benefit, day students will also be able to enroll in the evening classes (when class size permits).

Stanton is aware that evening students tend to be older than the standard undergraduate day students and that older students have their own unique set of needs In order to serve this group of students effectively, Stanton conducted an open forum to gather feedback from the evening students. A lot of the conversation focused on the difficulties that older students had managing their complicated family, career, and academic lives. A primary concern of older students centered on their children. For obvious reasons, childcare concerns were particularly prevalent among single parents. Concerns about possible evening child care issues tended to fall into three categories: structure, safety, and cost. The following information was gathered during this session.

\section{Structure}

- $\quad$ "I really like the evening class I took. However, it was a big hassle to get someone to watch my little girl while I was at class. I'm not sure how I'm going to arrange child care for next semester."

- $\quad$ "Maybe the college could run a clearing house for babysitters? I'd really prefer that someone came to my house, rather than I bring my child here. Don't your day-time college students want to make money?"

- $\quad$ "Maybe the college could arrange for kind of a babysitting co-op. You know, you watch my kid on Monday night at your home and I want your kid on Tuesday night at my home."

- $\quad$ "I wish I could just bring my little boy with me to campus. Maybe he could take a class, while I take class? Then he could learn something, too! You know, kind of like Kiddy Kollege!"

- $\quad$ "I don't want my child in a formal class in the evening. She's tired out after a full day at school. I think I just want her to relax and have fun and enjoy herself. I'd prefer Kiddy Kamp!"

- "Could there be homework help for my 8 year old?"

- "Would you offer evening care for all ages? Would the kids be separated by age or all mixed together?"

- "I would be nervous about having middle school kids rough-housing in the same room with my baby."

- "Where would you do this, if it was on campus?"

\section{Nutrition and Physical Needs}

- $\quad$ "My class isn't over until 9 pm. My 5 year old is usually in bed by $8 \mathrm{pm}$. Can she nap while I'm in class? Will she get anything to eat? What if she gets hungry? I'm really not sure bringing her to campus is a good idea."

- "Feeding the kids after work and before class is always a problem. I am so sick of fast food in the car!"

- $\quad$ "Would you take babies and children still in diapers? I want to get my education re-started while my children are little." 


\section{Safety}

- "My child's regular day care has a great number of rules and regulations about all sorts of things. Would your evening care have the same sort of standards to follow? For example, how many caregivers have to be present for every child? Would you take my child if she has the sniffles or a fever? Would it be regulated by the State? Would you be insured?"

- $\quad$ "How would you keep my child safe? I'm worried not only about possible pedophiles, but also about someone just picking her up and walking out with her in a crowded situation!"

- "How would you discipline my child if she misbehaves?"

\section{Cost}

- $\quad$ "I could pay a little for on-campus care, but not a lot. It would need to be affordable."

- "I don't have any money. Could I trade my time for evening care?"

- "If I go out for the evening, could I use the college evening care for babysitting services, too?"

- "Why can't the College subsidize the child care out of our tuition money? They charge enough for classes."

- $\quad$ "Would I have to schedule the care for the entire semester? How flexible could you be? Would you make me pay for evenings that my child didn't attend?"

\section{Overview of Your Group Project}

- $\quad$ Collect all additional information that you deem appropriate and necessary.

- Formulate a business response/solution to this Business Opportunity Statement.

- $\quad$ Analyze and evaluate the financial viability of your proposed solution.

- $\quad$ Refer to the Team Project Description for the detailed Project Requirements, Deliverables, and Due Dates. 


\section{APPENDIX 2}

\section{Business Opportunity Statement}

Fun Anyone?

Stanton College is a small, Liberal Arts residential college located outside of Boston, Massachusetts. Its 3,000 students are evenly distributed among its three major schools of Liberal Arts, Science, and Business. Historically, Stanton has concentrated on full-time Bachelors and Masters Programs and almost $90 \%$ of its students live on campus.

Stanton students have been complaining about the lack of regular entertainment options that are available on-campus during the weekends. In general, only about $20 \%$ of students maintain cars on campus. Public transportation is limited, and there are very few eateries or entertainment options within walking distance. This lack of both transportation and entertainment has led to a "perfect storm" of student boredom on the weekends. A number of students recently raised this issue at a Student Government Association meeting. Their comments fell into 4 basic categories: Type of Entertainment, Affordability, Location, and Safety Issues.

\section{Type of Entertainment}

- "I want someplace to go in the evening on campus. I want to just hang out, listen to live music, and maybe have a cup of coffee or a drink, and a snack."

- $\quad$ "I get so tired of just hanging out in the Dining Hall or Library.... I want to have some fun!"

- $\quad$ "I really like to go to bars. I like the casual atmosphere and meeting people. Can we have a pub on campus?"

- $\quad$ "A lot of kids just drink in their rooms and have parties. Won't on-campus activities have to compete with that type of thing?"

- $\quad$ "I'd love to see current movies on campus."

- "How about a bowling alley or a roller rink or a laser tag?"

- $\quad$ "I don't want to go to an on-campus pub, if there's no liquor. I'd rather just go into town with my friends to drink."

- " $\quad$ "I'd rather have a non-alcoholic pub. I hate hanging around drunks."

- $\quad$ "A game room would be fun, with all the latest video games and maybe some classic pinball. But most arcades are too expensive for me to go to them regularly...."

- "How about something healthy.... Like Zumba classes or drop-in aerobics, with a juice bar?"

\section{Affordability}

- "It needs to be cheap.... I don't have much money..."

- $\quad$ "I'd be willing to pay a bit to stay on campus. I wouldn't have to scrounge up a ride or gas money to get somewhere!"

- "Would Stanton be willing to subsidize something out of the Student Activity Fees?"

- "Could I work at the new place and make money? Or trade my labor for fun - kind of like a co-op?"

\section{Location}

- $\quad$ "There may be some houses for sale within walking distance. Could any of them be renovated into something for the students?"

- "Could we use the empty classrooms or lecture halls on the weekends or evenings?"

- $\quad$ "Could we build something? It seems like there is a lot of land available on campus, outside of the main academic quad."

- $\quad$ "Would parking be an issue for non-residential students or visitors?" 


\section{Safety Issues}

- "If it was on-campus, does that mean that the locals couldn't come? They have money to spend!"

- "My boyfriend goes to another local college. Could I bring him?"

- " $\quad$ "How do you handle under-age students, if you allow drinking?"

- $\quad$ "I wonder how the Campus Security Police would feel about the evening activities. Would we need to pay for extra security?"

- "What's the College Alcohol Policy?"

- $\quad$ "How late could this be open? Would I have to walk back to my dorms late at night, alone, in the dark? Would it be safe?"

- $\quad$ "How many students should we plan for? I'm concerned that if it's boring, no one will come. However, if it's great, we'll be overcrowded? How would we control crowds?"

\section{Overview of Your Group Project}

- $\quad$ Collect all additional information that you deem appropriate and necessary.

- $\quad$ Formulate a business response/solution to this Business Opportunity Statement.

- $\quad$ Analyze and evaluate the financial viability of your proposed solution.

- $\quad$ Refer to the Team Project Description for the detailed Project Requirements, Deliverables, and Due Dates. 